\title{
Stunting and Human Catastrophe in the Future (Analysis of Case Stunting in Indonesia)
}

\section{Salesman $\mathrm{F}^{*}$ \\ Institute of Health Sciences Citra Husada Mandiri Kupang, Indonesia}

*Corresponding author: Frans Salesman, Institute of Health Sciences Citra Husada Mandiri Kupang, Indonesia, Tel: +6281337909998; Email: franssalesman@gmail.com

\section{Opinion \\ Volume 2 Issue 2}

Received Date: March 08, 2019

Published Date: March 12, 2019

DOI: $10.23880 /$ jqhe-16000114

\section{Abstract}

Stunting as an event of failure to grow as a normal human is indicated through measurements of height / age, weight/age, and various other anthropometric measurements. If it continues to adulthood, it will lose the opportunity to enjoy higher education and certain types of work that require high height and weight, even though the position promises high salary/wages to strengthen purchasing power in the family and savings for investment. The failure to deal with stunting since the embryo and the growth of children and adolescents has caused future disasters for the child concerned and for the country. This article is a content analysis of the current stunting conditions in Indonesia and the future impacts.

\section{Introduction}

Indonesia is included in 47 countries out of 122 countries that have a prevalence of stunting in the world. Stunting as an event of failure to thrive as a normal human is indicated through the results of measurements of height / age, weight / age. The causes of stunting are grouped into:

(1) Direct causes: lack of nutrition, infectious diseases;

(2) Indirect causes: accessibility barriers to health service centers, child care during growth; and availability of food in the family. The two causes are motivated by poverty, the low level of education of the household head, availability of food in the community, and lack of employment.

The prevalence of stunting in Indonesia in 2013 and 2018 was reported by the Indonesian Ministry of Health in 2018. Indicated infants under five years of age in Indonesia; short in 2013 as many as $19.20 \%$, in 2018 as much as $19.30 \%$; very short in 2013 as much as $18 \%$, in 2018 as many as $11.50 \%$. The number of people with malnutrition in 2013 was $5.70 \%$, in 2018 as many as $3.90 \%$. Underweight sufferers in 2013 were $13.90 \%$, in
2018 as many as $13.80 \%$. Overweight sufferers in 2013 were $11.80 \%$ and decreased to $8 \%$ in 2018 . The number of infants under five years of age who received complete basic immunization was $57.90 \%$, incomplete immunizations $32.90 \%$, and did not receive immunization $9,20 \%$.

\section{Catastrophe in the Future}

Stunting during the baby's growing up to adulthood will lose the opportunity to reach several opportunities available that require minimum height requirements. For example, a nursing university requires a minimum height of $1.60 \mathrm{M}$. Higher education educates prospective pilots (pilots), Flight Attendants / Stewards need a minimum height of $1.75 \mathrm{M}$. Prospective members of the Indonesian Armed Forces, and Republic of Indonesia Police in addition to being healthy, also require height minimum body of $1.70 \mathrm{M}$. Higher education and / or certain types of work that require a certain minimum height prerequisite will get relatively high salary / wages to support purchasing power in the family, and maybe the rest will be saved for investment in housing, cars, and health insurance. The analysis conducted by the Indonesian 


\section{Journal of Quality in Health Care \& Economics}

National Development Planning Ministry states that "Stunting can cause economic losses to the Indonesian state by $2-3 \%$ of the Gross Domestic Product (GDP) per year. If our country's GDP is Rp. 13,000 trillion in 2017, it is estimated that the potential losses due to stunting in Indonesia can reach Rp. 300 trillion per year."

Economic losses analyzed by the Indonesian National Development Planning Ministry as a catastrophe experienced by the Indonesian people at this time, caused by negligence in overcoming stunting mitigation in the past, Strategies for managing stunting migrations can be done through; increase in embryonic nutrient intake until the age of 2 years in the form of micro and macro nutrition, protein, and energy, parenting and health care for children from the womb of their mothers until the age of five, access to basic health services and referrals, environmental sanitation, poverty reduction, power strengthening buy in the family, control the prices of food reached by the poor, and birth control to reduce the burden on the family.

\section{Conclusion}

If everyone is aware that stunting can cause future catastrophe, a baby under five years accumulatively causes losses to the State, mitigation efforts will be carried out in the form of improving infant nutrition from the embryo to the age of someone's teenager, and improving Socio-economic external conditions in the community.

\section{Disclaimer}

This opinion is my analysis of the stunting situation in Indonesia which was explored and developed from a literature review and the results of 2018 Basic Health Research published by the Ministry of Health of the Republic of Indonesia. 